Revista Española de Antropología Americana ISSN: 0556-6533

https://doi.org/10.5209/reaa.66525

\title{
Gesto y rango en el arte maya clásico
}

\author{
Erik Velásquez García ${ }^{1}$
}

Recibido: 5 de marzo 2019 / Aceptado: 26 de septiembre de 2019

Resumen. Los artistas mayas del periodo Clásico, especialmente en su fase tardía (600-800 d.C.), cristalizaron un sistema o aparato de convenciones visuales, cuya finalidad era enaltecer y glorificar la figura de sus k'uhul ajawtaak o señores divinos. El estudio de este corpus de estrategias, que apenas está en sus albores, constituye el tema de reflexión de este artículo, que por sus dimensiones no es un estudio exhaustivo, sino más bien introductorio. Éstas incluyen la división jerárquica del campo pictórico, la manipulación de escalas y volúmenes, el uso de determinada indumentaria y parafernalia política y ritual, la presencia de títulos de cargo y rango escritos en las glosas, las interacciones entre los personajes, los recursos del halo o hueco jerárquico, ángulos simultáneos de visión, principio de diferenciación, escalonamiento vertical de las figuras, actitud isocefálica entre personajes del mismo estatus, distanciamiento emocional entre el gobernante y los individuos de bajo rango y la tensión psicológica que se produce entre recursos narrativos vernáculos y hieráticos-idealizados de filiación teotihuacana, todo lo cual en su conjunto es lo que le da sentido y significado a las posturas, gestos y ademanes, que suelen resaltar sobre fondos neutros o poco recargados, donde el medio ambiente, entorno o panorama es conceptual y minimalista.

Palabras clave: convenciones visuales; lenguaje gestual; campo pictórico jerarquizado; hueco jerárquico; principio de diferenciación.

\section{[en] Gesture and Rank in Classic Maya Art}

\begin{abstract}
The Mayan artists of the Classic Period, especially in its late phase (600-800 AD), crystallized a system or apparatus of visual conventions, whose purpose was to enhance and glorify the figure of their k'uhul ajawtaak or divine lords. The study of this corpus of strategies, which is barely in its infancy, is the subject of reflection of this article, which by its dimensions is not an exhaustive study, but rather introductory. These include the hierarchical division of the pictorial field, the manipulation of scales and volumes, the use of certain clothing and political and ritual paraphernalia, the presence of titles of position and rank written in the glosses, the interactions between the characters, the resources of the halo or hierarchical hollow, simultaneous viewing angles, principle of differentiation, vertical staggering of figures, isocefalic attitude between characters of the same status, emotional distancing between the ruler and low-ranking individuals, and the psychological tension that occurs between vernacular narrative resources and hieratic-idealized of Teotihuacan affiliation, all of which is what gives meaning and meaning to the postures and gestures, which tend to stand out on neutral or little recharged backgrounds, where the environment, environment or panorama is conceptual and minimalist.
\end{abstract}

Keywords: Visual conventions; gestural language; hierarchical pictorial field; hierarchical hollow; principle of differentiation.

\footnotetext{
1 Instituto de Investigaciones Estéticas, Universidad Nacional Autónoma de México. inkabaeeric@gmail.com.
} 
Sumario. 1. Introducción. 2. Principios generales. 3. Frontalidad versus lateralidad. 4. Postura corporal y jerarquía. 5. El principio de verticalidad. 6. Los cautivos y sus captores. 7. Reflexiones finales. 8. Referencias.

Cómo citar: Velásquez García, Erik. 2019. «Gesto y rango en el arte maya clásico». Revista Española de Antropología Americana 49: 131-150.

\section{Introducción}

Hace décadas Tatiana A. Proskouriakoff (1950: 23) observó que la representación de los ademanes y posturas corporales es un fenómeno relativamente tardío en el arte maya, pues se relaciona con el abandono de las poses estáticas recargadas de atuendos y accesorios, que caracterizaron la escultura del Clásico Temprano. Como ejemplos de esta ausencia de dinamismo durante el Clásico Temprano contamos con las estelas de Tikal (1, 2, 7, 8, 12, 13, entre otras), Uaxactún (Estelas 9 y 20), o el Monumento 26 de Quiriguá (Figura 1), entre otros.

Beatriz de la Fuente (2004: 56-60, 62-66) clasificó las diferencias entre la escultura del Clásico Temprano y la del Tardío como dos posturas asumidas por el hombre maya frente a las categorías de tiempo y espacio. Por una parte, las imágenes estáticas, solemnes, hieráticas y autocontenidas del Clásico Temprano revelan una realidad donde el espacio se ha cerrado para capturar el tiempo; implican una percepción distante, en el más allá, en la atemporalidad del espacio indefinido del anecúmeno (López Austin 2015) o ámbito sagrado, que trasciende la percepción humana. Por el contrario, el arte vitalista, narrativo y con tema humano del Clásico Tardío refleja un firme anclaje en el tiempo y el espacio (Figura 2), lo que se traduce en una particular conciencia del ecúmeno o ámbito mundano de las criaturas, sujeto a la percepción sensorial.

En pocos temas puede admirarse mejor este desarrollo del arte narrativo que tuvo lugar durante el Clásico Tardío como en las escenas cortesanas mayas que, por estar desarrolladas en torno a la figura del gobernante, fueron un medio adecuado para representar interacciones sociales. Los artistas que elaboraron estas imágenes hicieron uso de un extenso repertorio de recursos iconográficos para manifestar el estatus social de los personajes, mismo que ha sido abordado principalmente por Stephen D. Houston (1998: 341-348) (ver también Marcus 2006: 217-220). El análisis presentado por él, así como el trabajo que expongo ahora, que retoma temas trabajados en mi tesis doctoral (Velásquez 2009: 262-351), sugiere que el código de los artistas mayas para comunicar interacciones humanas no se reducía al uso de posturas y ademanes, sino que éstos adquieren sentido al combinarse con una serie de fórmulas que incluyen diferencias de escala y proporción, la relación espacial entre los individuos, así como su distribución codificada en el campo pictórico (Miller 1981: 24).

\section{Principios generales}

El énfasis de las escenas parece encontrarse en las interrelaciones humanas que revelaban jerarquías sociales (Figura 3), hasta el punto que la representación de los espacios interiores, arquitectura y sus detalles, suele estar apenas sugerida por unos cuantos elementos, como cortinas, cojines, plataformas o banquetas bajas y pilastras 

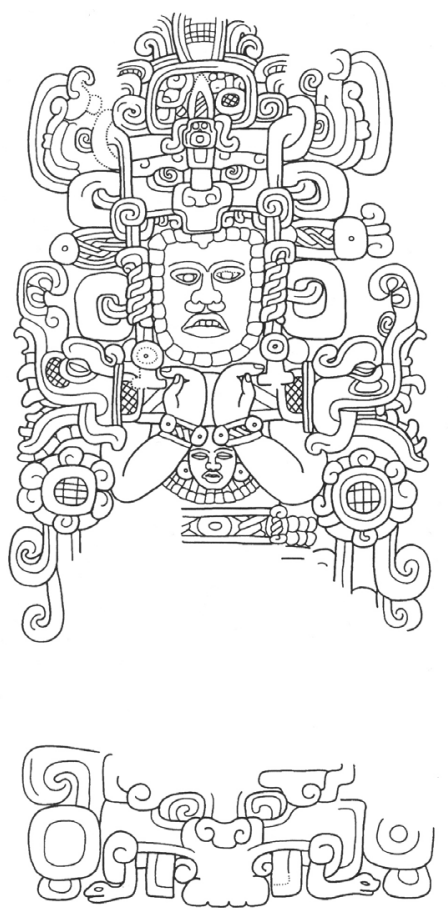

Figura 1. Monumento 26 de

Quiriguá, con personaje frontal y sin dinamismo (según Looper 2003: 41, fig. 1.6).
Figura 2. Bonampak, Cuarto 2 , muro sur, detalle superior derecho donde se advierte el movimiento de los personajes en el fragor de la batalla (según Miller y Brittenham 2013: 98).

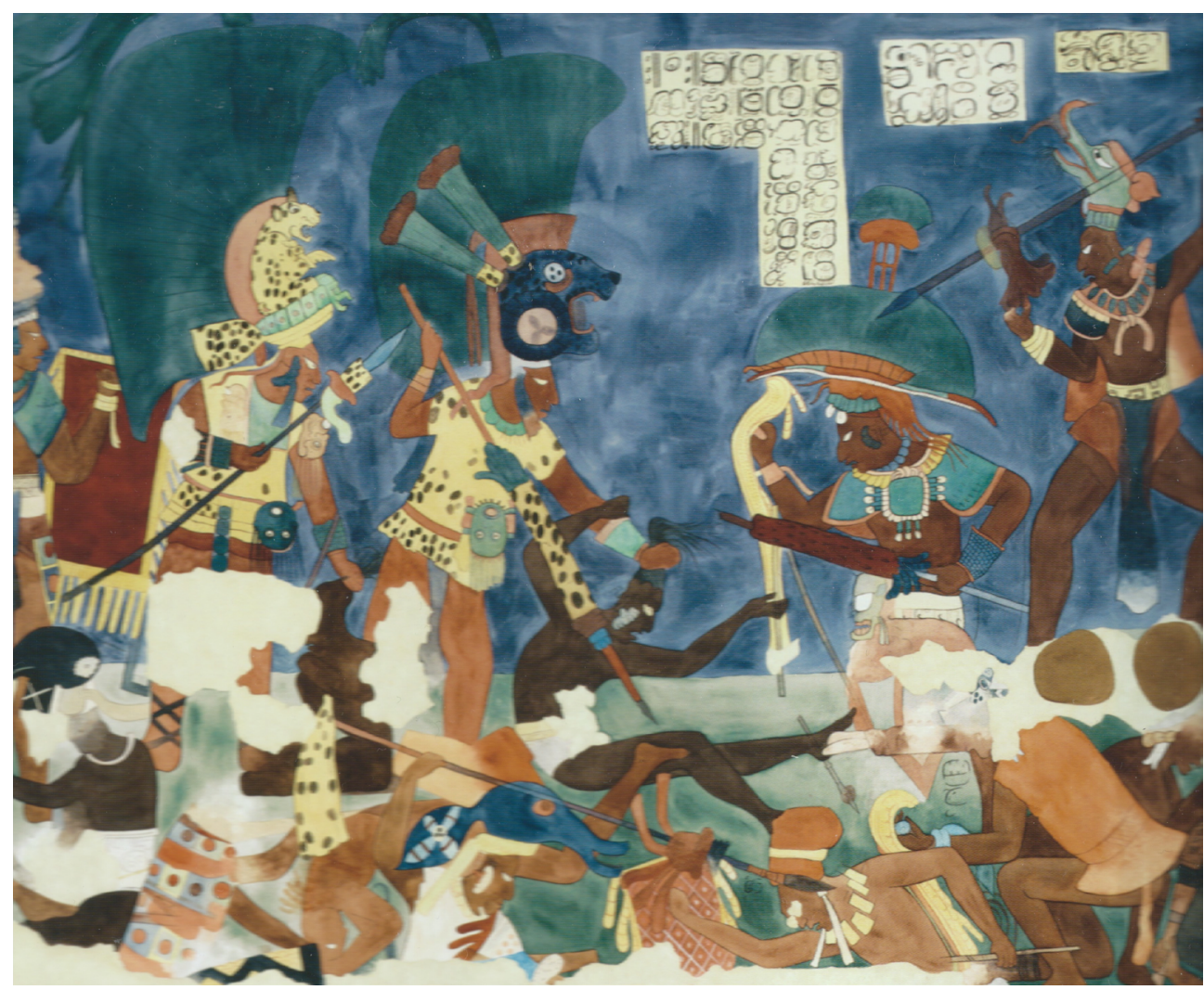




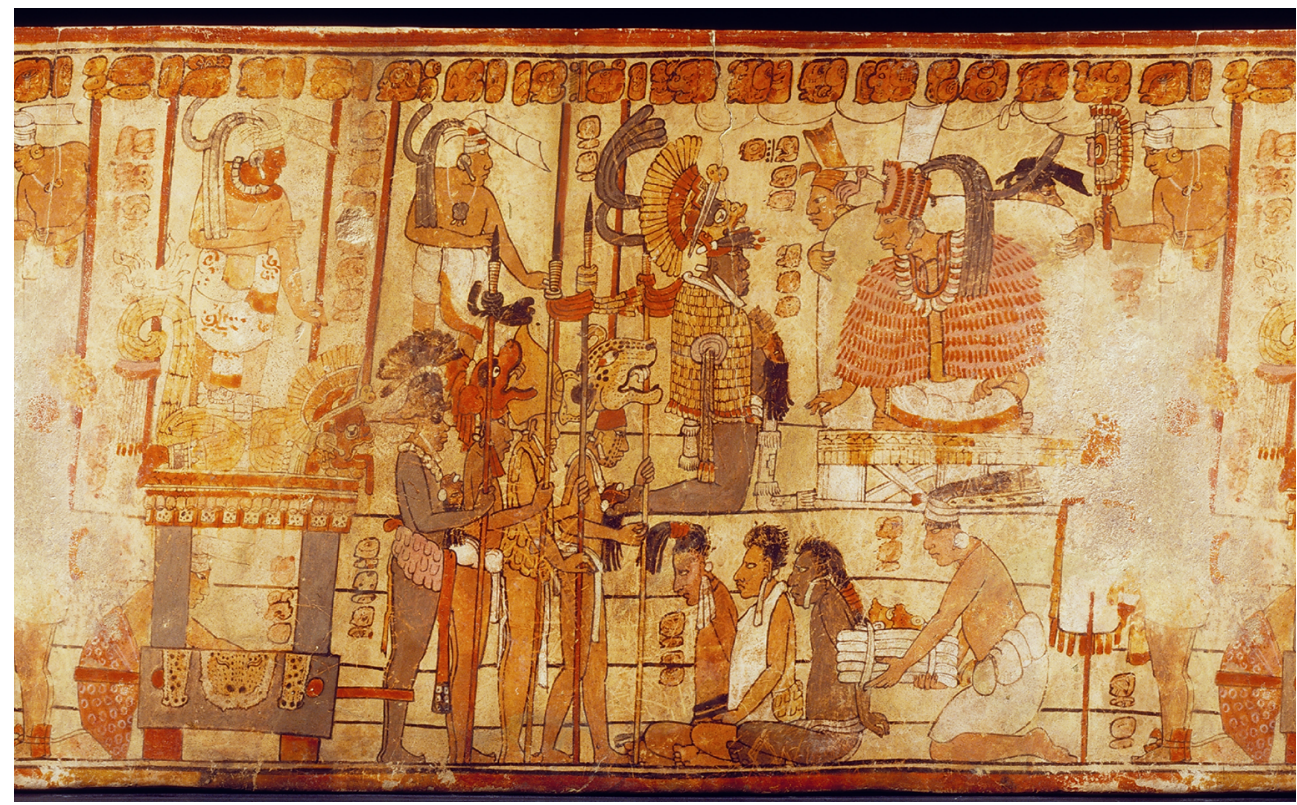

Figura 3. Escena de corte donde se advierten las jerarquías sociales (cortesía de Justin Kerr, Justin Kerr Maya vase archive, K3412, Dumbarton Oaks, Trustees for Harvard University, Washington, D.C.).

que enmarcan las imágenes (Reents-Budet 2001), pues el detalle está concentrado en la interacción de los personajes, cuya identidad y estatus es revelado por sus atavíos, gestos, acciones, parafernalia y posición relativa dentro de las escenas, más que por sus características faciales (Robicsek y Hales 1981: 9; Houston 2004: 288). De esta forma, un fondo neutro, simple o poco recargado, permite enfatizar con elocuencia los ademanes y posturas corporales que definen el rango social de los individuos.

La composición de estas escenas gira en torno a la figura del soberano de pie o entronizado, ubicándolo entre dos hileras de personajes sedentes o de pie o agrupando la procesión en una fila única de individuos ligeramente yuxtapuestos, que se alinean frente al trono viendo a la derecha del observador. Esta es una convención muy generalizada en el arte narrativo maya.

De acuerdo con Houston (1998: 341) entre la persona que mira hacia la izquierda -usualmente entronizada- y la primera del grupo que mira a la derecha se ubica la zona de contacto o locus simbólico donde se encuentran los personajes de mayor rango, si bien hay excepciones a esta regla. Los individuos que aparecen a la derecha del observador, detrás del señor entronizado, son usualmente sirvientes o asistentes. La jerarquía relativa de los personajes se encuentra definida por una serie de convenciones que forman parte del canon iconográfico de la civilización maya clásica, donde no sólo importan las posturas, ademanes, títulos y atuendos, sino la posición que ocupa cada figura dentro del campo pictórico, pues el espacio no es homogéneo, sino relacional y jerárquico, como ya fue apreciado en un trabajo pionero por Stephen D. Houston y David Stuart (2001: 62).

Una de estas convenciones consiste en que la zona derecha de las escenas constituye el flanco más favorecido, donde suelen ubicarse los individuos en los cuales 


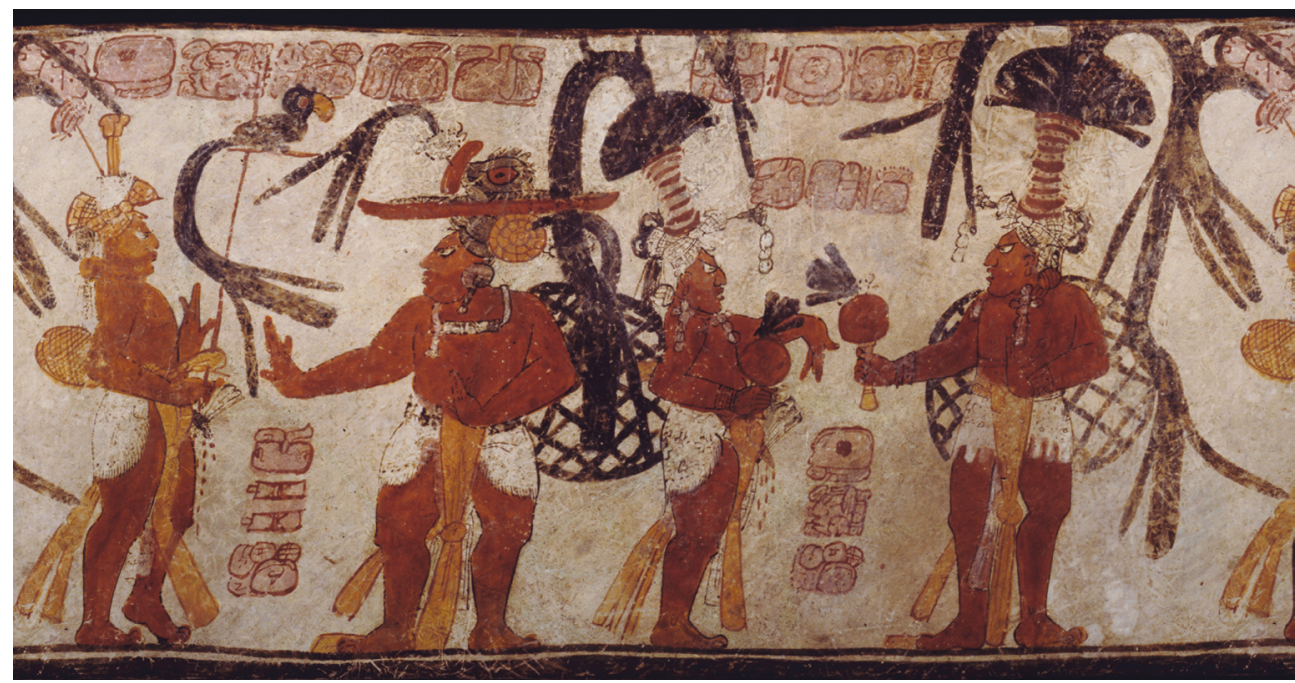

Figura 4. Escena de danza donde se aprecia el principio de énfasis horizontal (cortesía de Justin Kerr, Justin Kerr Maya vase archive, K1399, Dumbarton Oaks, Trustees for Harvard University, Washington, D.C.).

radica el énfasis de la composición, si bien éstos no siempre coinciden con los de mayor rango político (ver Miller y Martin 2004: 187). Cabe advertir que en imágenes donde intervienen varios personajes lo anterior sólo es aplicable para el primer individuo de la procesión que mira hacia la izquierda, que en el caso de las composiciones con tema cortesano casi siempre es un dignatario entronizado o de pie. El resto de los participantes ubicados en el flanco derecho usualmente se ubican a las espaldas del individuo más importante y en la mayoría de los casos se identifican como sirvientes o vasallos de la corte. Este principio de énfasis horizontal puede apreciarse también en algunos vasos con tema de danza, como por ejemplo en la vasija K1399 (Figura 4) (ver Reents-Budet et al. 1994: 170-171; Just 2012: 189-191), donde las cláusulas nominales ayudan a comprender que los danzantes ubicados a la derecha son gobernantes de Ik' $\mathrm{a}^{\text {? }}$, mientras que los individuos que ocupan el flanco izquierdo y ejecutan un autosacrificio fálico son sólo sacerdotes o adoradores $\left(a j k^{\prime} u h u^{2} n\right)$. Esta primacía de las figuras que están a la derecha del observador parece seguir el movimiento de los ojos mayas, acostumbrados a leer los jeroglifos de izquierda a derecha (Houston 1998: 342; Palka 2002). Semejantes principios para acomodar los objetos en el espacio pueden encontrarse entre algunos grupos mayances contemporáneos, como los chujes y tojolabales, quienes ordenan las cosas de derecha a izquierda, pues en sus lenguas queda implícito que el punto de donde debe partirse para distribuir los elementos es la derecha, que corresponde al punto principal (Schumann 1981: 135).

\section{Frontalidad versus lateralidad}

En la cúspide social está el ajaw o k'uhul ajaw, 'señor divino' (Figura 5), cuya superioridad se encuentra establecida por su entronización misma, por la procesión de asistentes que se mueven hacia él, por sus atuendos de realeza (que tienen la 


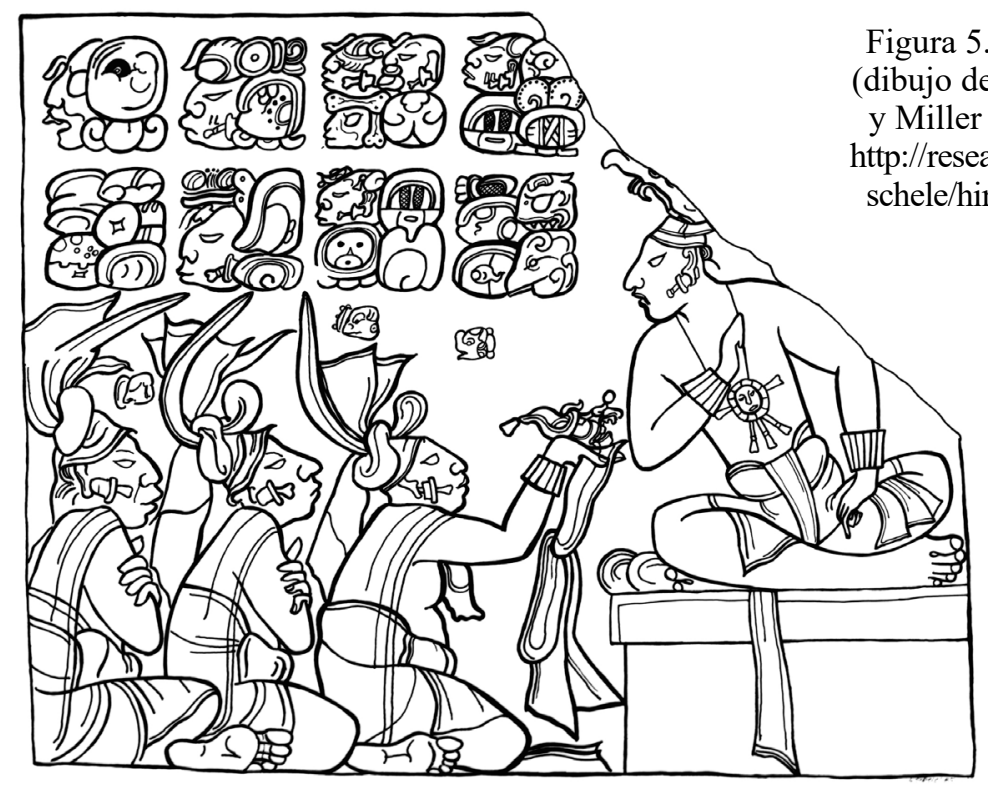

función de exaltar la importancia de su usuario) y por el espacio que marca la distancia entre él y sus súbditos. A estas convenciones se puede agregar otra, que parece haber pasado casi inadvertida: la inclinación del soberano ${ }^{2}$. Esta postura se lograba representando el rostro de perfil, con un hombro caído y otro alzado, revelando una porción del cuello. Con ello se lograba un retrato convincente que captaba el cuerpo girando hacia un lado (Miller 1999: 158). Aunado a lo anterior, el soberano elevaba una de sus manos a la altura del pecho, y cuando adoptaba una postura sedente solía apoyar la otra sobre el muslo o cerca de la rodilla. Aunque algunos autores (Benson 1974: 111; Ancona-Ha et al. 2000: 1075; Pérez de Lara 2002: 2-5) consideran que simplemente se trata de una pose propia de figuras de alto rango, lo más lógico es -siguiendo una idea de Mary E. Miller (1999: 154)- que la posición de las manos sea también una estrategia artística para equilibrar el centro de gravedad de estas figuras inclinadas. El sentido social de esta postura desequilibrada del gobernante fue atisbado ya por Proskouriakoff (1950: 28-29), quien observó que aparece en el arte maya a partir de 672 d.C., pero sólo en composiciones grupales; dos $k$ 'atuunes después, en 711 d.C. (9.14.0.0.0), comenzará a ser aplicada en las figuras de pie que aparecen en las estelas y en los vasos, como en la vasija K3460 (Figura 6), donde la inclinación del dorso real conserva la carga simbólica de bajar para atender a los individuos de rango inferior. Esta acción no es gratuita, sino que tiene la función práctica de permitir que la sirvienta pinte los labios del monarca, quien se dispone a participar en una danza dramatizada.

Elizabeth P. Benson (1974: 110; ver también Halperin 2004: 56; Pérez de Lara 2002: 5) sugirió que la proyección frontal de la figura del gobernante maya era otro elemento propio de la diferenciación de rango, ya que el resto de los personajes suelen aparecer representados de costado para manifestar su menor estatus, idea

\footnotetext{
2 Entre esos atuendos de realeza no deben olvidarse los penachos o tocados de plumas, que tienen la función de exaltar la importancia de su usuario y conllevan, por lo tanto, un simbolismo jerárquico y/o ritual (Winning 1987 II: 70).
} 


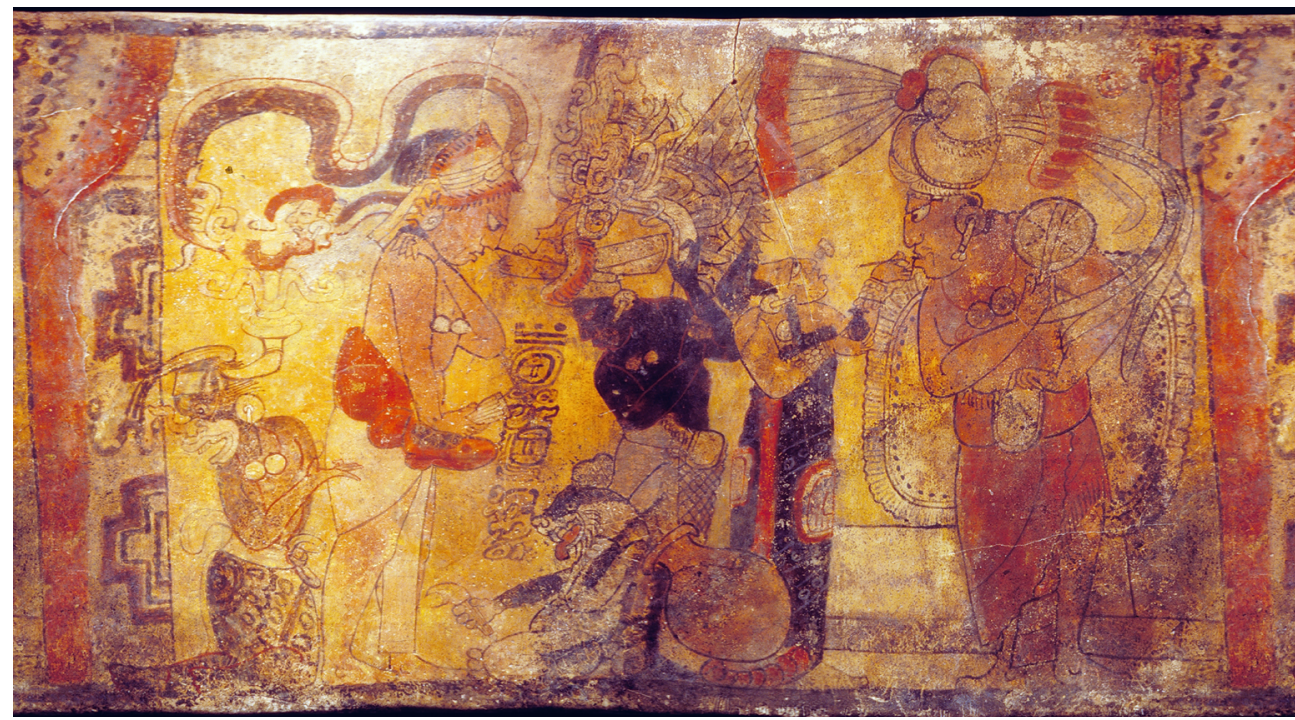

Figura 6. Escena del reino de Ik'a? donde el gobernante de pie se inclina hacia sus visitantes o vasallos, lo que simboliza que estos se encuentran en un estatus inferior (cortesía de Justin Kerr, Justin Kerr Maya vase archive, K3460, Dumbarton Oaks, Trustees for Harvard University, Washington, D.C.).

corroborada por Jorge Pérez de Lara. Esto parece ser válido en muchas ocasiones, aun entre los propios gobernantes, cuando el artista buscaba enaltecer a uno de ellos sobre el otro. Tal es el caso del Altar 12 de Caracol (Figura 7), donde K'ihnich Tob'il Yopaat (810-830 d.C.), el soberano local, se encuentra favorecido sobre su aliado de Ucanal al presentarse frontalmente y ocupar la posición privilegiada de la derecha. Diversos ejemplos de esta estrategia pueden encontrarse en el arte figurativo de los mayas. Figuras de alto rango suelen reconocer la superioridad del gobernante al aparecer sentadas a la izquierda (ver Figuras 3 y 5), siempre de costado y directamente sobre el piso, bajo el trono. Pero a pesar de esta preeminencia de la postura frontal sobre la lateral, en las imágenes bidimensionales (pintura y bajorrelieve) son escasas las figuras que aparecen con el rostro completamente de frente o mirando hacia el espectador, como se ve en las vasijas K680 y K5453. De acuerdo con Mary Miller (1999: 157-158) una norma constante en dichas representaciones es que se trata de cautivos de guerra o personajes de rango inferior.

Si bien esta estrategia de diferenciación de rango a través de la frontalidad puede encontrarse en muchas escenas narrativas mayas, también hallamos abundantes excepciones a la misma, en las cuales se privilegian otros recursos para sugerir el estatus social. Un ejemplo se encuentra en el vaso K4412 (Figura 8). No hay elementos para afirmar que alguno de ellos sea un gobernante, aunque la figura principal es obviamente el individuo pintado de color rojo. Su pintura corporal ya produce, de entrada, una diferenciación dentro del grupo, pero además él es el líder de la procesión de guerreros y recibe los honores de un individuo arrodillado. Un cautivo de guerra se enlaza con el personaje principal por medio de una soga que surge de braguero de su captor. Es obvio que sobre el cautivo recae toda la atención de la escena, pues se ubica en el centro de la composición, se encuentra en primer plano y se presenta 


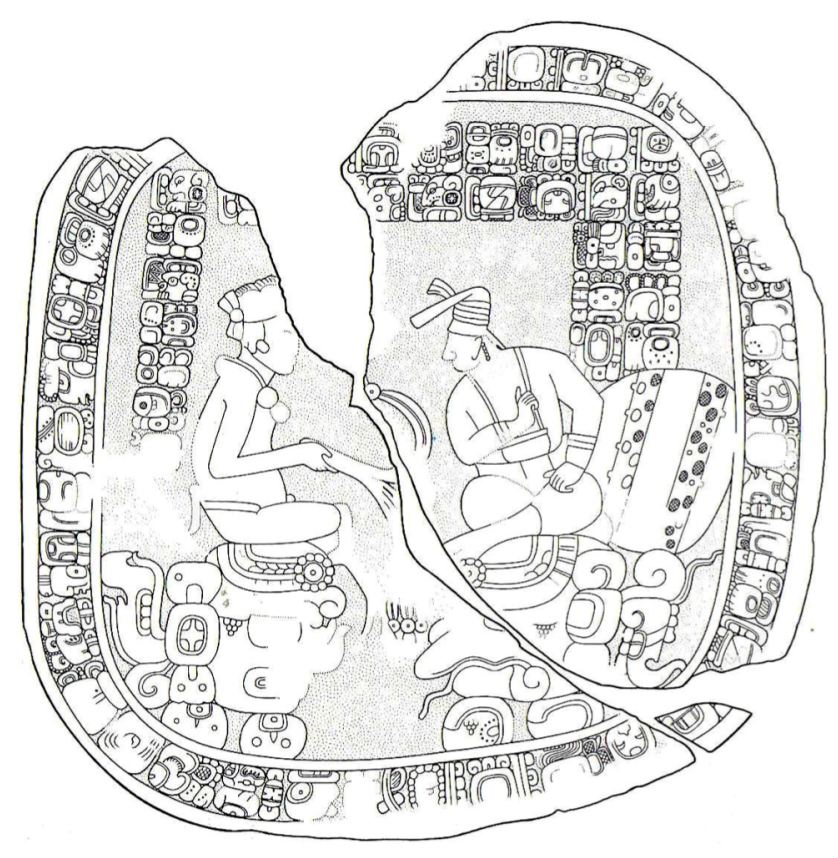

Figura 7. Altar 12 de Caracol (dibujo de Nikolai Grube en Martin y Grube 2008: 98).

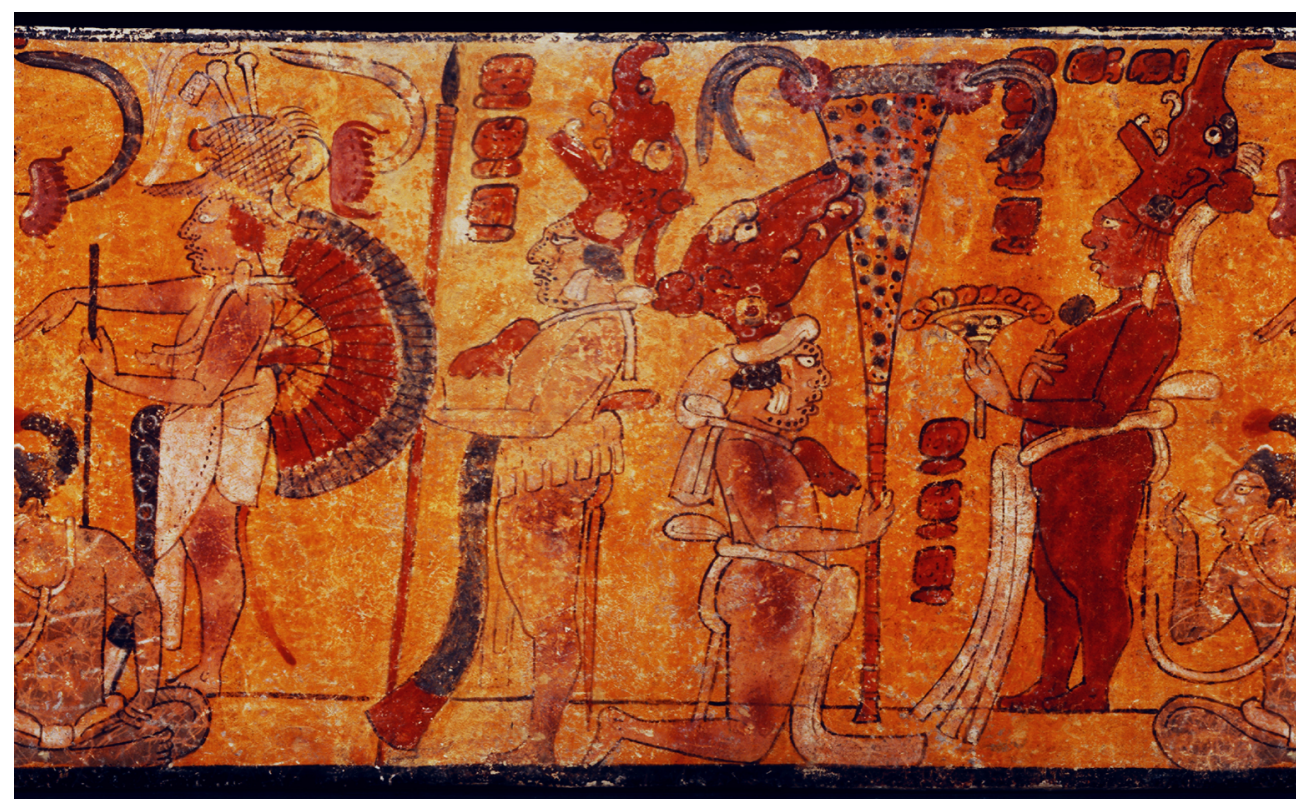

Figura 8. Escena sin elementos evidentes que distingan al gobernante, aunque la figura principal es el individuo pintado de color rojo (cortesía de Justin Kerr, Justin Kerr Maya vase archive, K4412, Dumbarton Oaks, Trustees for Harvard University, Washington, D.C.).

sentado, con el cuerpo de frente. No obstante, ello no produce una ambigüedad sobre su condición social, ya que se apoya sobre el piso menos elevado, se encuentra a las espaldas de la figura principal y es evidente que se trata de un cautivo de guerra. En 
este vaso podemos apreciar que el recurso de presentar a ciertos individuos de rango inferior con el dorso de frente tiene aparentemente la función de atraer hacia ellos la atención del espectador, más que una marca de estatus superior. Ello constituye un indicio de que las convenciones pictóricas de los vasos mayas sólo deben entenderse como principios generales y no como reglas fijas o inmutables.

\section{Postura corporal y jerarquía}

Por regla general, las figuras de pie tienen un rango menor que las sedentes ${ }^{3}$ (ver Figuras 3 y 8), pues en varias tradiciones artísticas del mundo (Brilliant 1963: 45, n. 41,75$)$ estar de pie delante de otro es un gesto de honor a la persona del gobernante. Arrodillarse (ver Figura 5), en cambio, suele implicar una pose de sumisión, adulación, piedad o súplica ${ }^{4}$, así como el reconocimiento abierto de que se posee un estatus inferior. Es preciso aclarar que este sistema de jerarquías relativas a través de la pose corporal, donde sentarse es una posición de primacía, sólo parece funcionar en las escenas grupales o narrativas de tema palaciego, donde intervienen varios personajes, pues en el caso de composiciones donde el gobernante de pie es la única persona representada, acaso acompañado por cautivos (por ejemplo en las estelas 1, 4, 5, 6, 12 y 20 de Cobá o 26 de Piedras Negras, ver Figura 12) o por enanos (por ejemplo en las Estelas 1 y 5 de Caracol o 57 PJ 1359 del Museo Amparo), como sucede a menudo en las estelas, el artista maya suele enfatizar la jerarquía del mandatario a través de figuras de dimensiones empequeñecidas o arrodilladas que lo flanquean, lo asisten o le sirven como apoyo físico.

Un caso célebre de enaltecimiento social a través de la postura frontal y sedente a una mayor altura que el resto de los figurados, se encuentra en un vaso que procede del Entierro 116 de Tikal (Figura 9), donde el rango social y la importancia visual de cada personaje se encuentra designado por su postura corporal y en cierto modo por el lugar que ocupan dentro de la escena, independientemente de los ademanes que realizan. Primeramente, se encuentra el gobernante, Jasaw Chan K'awiil I (682-734 d.C.), cuya condición de soberano es notoria por estar sentado frontalmente, recibir la atención de los demás personajes y ubicarse en la posición más elevada, lo que lo obliga a inclinarse para atender a sus vasallos o visitantes. Este hecho, y el de ser el único que está sentado, contribuye a diferenciarlo del resto de los individuos, enfatizando con ello su más alto rango, pues un elemento básico en la marcación de estatus es la distinción de una figura dentro del grupo. Richard Brilliant (1963: 42, 50) ha llamado a esta estrategia iconográfica el «motivo de la diferenciación», y de acuerdo con Ernest Gombrich (1987: 106) se basa en que nuestro cerebro no está originalmente programado «para la percepción del parecido, sino de la diferencia, o apartamiento de la norma que destaca y se fija en la mente».

En el vaso del Entierro 116, en segundo lugar, se encuentran los personajes que ascienden por los escalones y le llevan regalos. Su importancia relativa dentro de la composición queda sugerida por su mayor proximidad a la figura del gobernante (Houston y Stuart 2001: 62-63), lo cual en este caso no parece coincidir con sus

\footnotetext{
3 Mary E. Miller (1999: 71-72) opina que la primacía concedida en el arte maya a la posición sedente obedece a que simboliza el concepto de entronizarse (chumlaj ti ajaw[i]l, 'se sentó en el señorío').

4 En los documentos quichés arrodillarse era un símbolo de piedad ante los dioses (ver Christenson 2003: 228).
} 


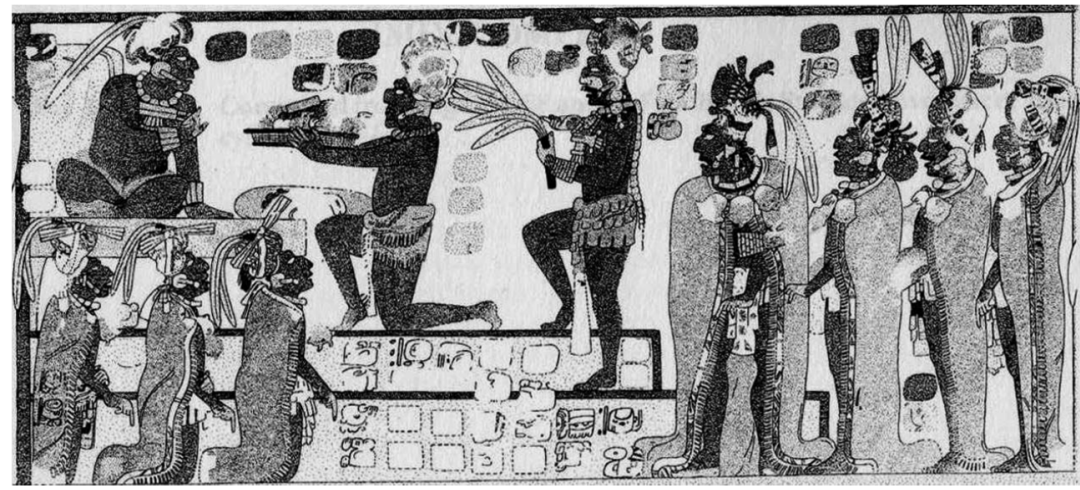

Figura 9. Vaso del Entierro 116 de Tikal, tumba de Jasaw Chan K'awiil I (682-734 d.C.) (Culbert 1993: fig. 68).

rangos sociales, pues no llevan atuendos tan ricos y su función es entregar presentes al soberano. No obstante, debido a su ubicación ellas son las segundas figuras visualmente más importantes en la composición, no así en la jerarquía social. El énfasis y la jerarquía no siempre coinciden en el código de los artistas mayas. Un tercer nivel es el que ocupan los funcionarios que están de pie, tres de los cuales igualan su condición mediante el uso de atuendos y ademanes semejantes, así como por su actitud isocefálica, al ser retratados con la cabeza en una misma altura. El primer individuo de la procesión, sin embargo, se diferencia de los otros por su volumen, cuerpo frontal y mayor proximidad a los personajes de alto rango. Su cabeza se encuentra aislada de las otras por un espacio que la enmarca y la libera, constituyendo una especie de hueco jerárquico o espacio abierto (Miller 1999: 149) ${ }^{5}$. Es importante observar que en esta escena la procesión de personajes que se dirige al mandatario entronizado entra por la derecha, situación que de acuerdo con Houston (1998: 342), puede implicar una noción de visita a algún sitio extranjero.

Los últimos en estatus son los personajes arrodillados de la esquina inferior izquierda, aunque el primero de ellos parece destacarse de los otros por la ligera desigualdad de su masa corporal. Cabe resaltar que, aunque físicamente se encuentran más próximos al gobernante, su menor jerarquía queda de manifiesto por su postura corporal (están arrodillados), la menor altura de sus cabezas y su colocación en el lado izquierdo de la escena. Si bien el gobernante ocupa el lugar principal dentro de la imagen, otros elementos, tales como su mayor elevación, su posición sedente y su diferenciación radical del resto de las figuras, lo destacan como el personaje de mayor estatus.

Virginia E. Miller (1983: 24, 33) no encontró diferencia alguna clara en el sentido de los ademanes que ejecutan los siete personajes entogados de este vaso, y tuvo que concluir que probablemente poner una mano en el hombro opuesto era básicamente equivalente a sujetarse uno de los antebrazos. Según sus propias observaciones, parece tratarse de un saludo propio de viajeros y dignatarios visitantes. La clave de la variación probablemente no reside en matices semánticos específicos, sino en un principio formal que fue señalado por Pablo Escalante (1996: 323-324, 326-328,

\footnotetext{
Para el concepto del «hueco jerárquico» ver el útil e ilustrativo trabajo de Brilliant $(1963: 42,50)$ sobre el arte del Imperio Romano.
} 
361): «el pintor introduce cambios a intervalos para evitar la repetición exagerada de un rasgo»». Al evitar la repetición monótona de un mismo ademán, el artista contribuye a crear una obra clara y comprensible, donde el observador puede localizar información visual de una forma expedita.

Como Houston y Stuart (2001: 62-63) han advertido, la jerarquía relativa de cada personaje suele estar determinada por su mayor o menor distancia respecto a la figura del soberano. No obstante, como vimos en el caso anterior, ésta no parece haber sido una regla estricta, pues el énfasis visual sobre ciertos personajes no siempre coincide con sus jerarquías sociales. Otro ejemplo notable se encuentra en el vaso K6984, donde el individuo que se encuentra más cerca del gobernante no sólo está arrodillado, sino que se inclina con suma reverencia y es señalado con el dedo índice por un personaje de pie que se encuentra detrás de él.

Una postura corporal poco frecuente en el área maya es la de los personajes que están de espaldas. En términos generales, es una pose asociada con asistentes o sirvientes (personaje de rango modesto dentro de las cortes reales), así como cautivos de guerra. No se trata de una postura visualmente convincente (Miller 1999: 157), puesto que los artistas mayas parecen no haber alcanzado el dominio anatómico de ella. Los pocos ejemplos que encontramos sugieren torsiones difíciles, forzadas y muy incómodas, implicando el uso de ángulos simultáneos de visión ${ }^{6}$.

Un ejemplo se encuentra en la Estela 2 de Machaquilá (Figura 10), ciudad ubicada al oriente del Petexbatún. El personaje que se contorsiona de espaldas en esa

\footnotetext{
${ }^{6}$ Los pintores de cerámica sacrificaron el ángulo de visión natural en aras de alcanzar la claridad e inteligibilidad máxima ante los ojos de los espectadores, por lo que en muchas ocasiones pintaron edificios o personajes que muestran simultáneamente partes imposibles de ver desde un mismo punto. Este ardid recibe el nombre de ángulo simultáneo de visión (ver Miller 1986: 147; Houston 1998: 344-345), recurso que se emplearía asiduamente en las tradiciones pictóricas del Posclásico Tardío, donde «las partes del cuerpo de una figura se pueden girar arbitrariamente hasta colocar cada una en su faceta más claramente identificable» (Escalante 1996: 274-275). Basada sin duda en las observaciones hechas por Gombrich (2006: 52-53, 66-68) sobre otras tradiciones artísticas del mundo antiguo, como la egipcia o la griega arcaica, Mary E. Miller explicó vehementemente que este tipo de recursos conceptuales no se basan en lo que el ojo humano puede ver, sino que apelan a lo que la mente sabe que hay, «resultando una figura humana que se mostraba totalmente» (Miller 2009: 138).
}

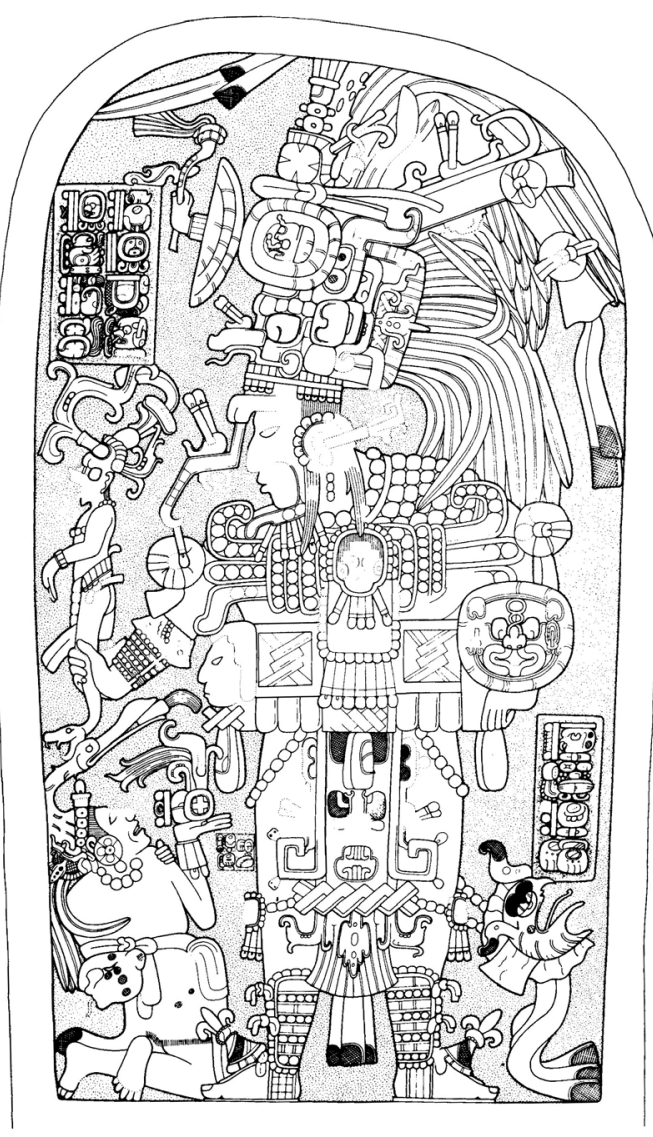

Figura 10. Estela 2 de Machaquilá. El cautivo aparece representado de espaldas, (Graham 1967: 63, Fig. 44). 


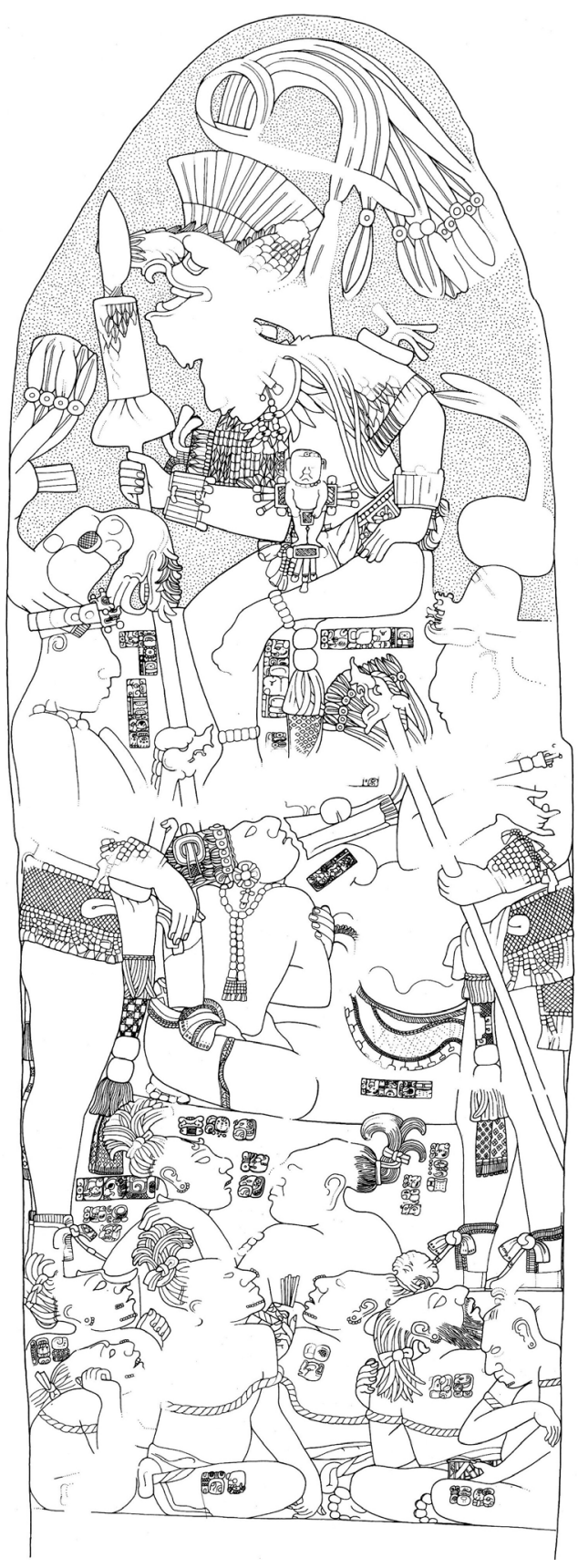

Figura 11. Estela 12 de Piedras Negras (795 d.C.). Aquí el rango de cada personaje se aprecia por el principio de verticalidad. El soberano se encuentra en la parte superior del monolito. (Dibujo de David Stuart, basado en fotografía de Maler e inspección del original, en Stuart y Graham 2003: 9:61). estela parece ser un prisionero de guerra, a juzgar por su cláusula nominal, que incluye la frase $u b$ 'aak, 'es el cautivo de'. Mary E. Miller (1999: 157) ha apuntado otro ejemplo de esta postura corporal en el cautivo que está en la parte superior del muro norte del Cuarto 2 de Bonampak.

\section{El principio de verticalidad}

Como ya ha observado Houston (1998: 343), en las imágenes mayas del periodo Clásico la jerarquía de cada personaje se encuentra sugerida mediante el principio de verticalidad, pues el espacio plástico se encuentra segmentado en niveles, que a su vez se corresponden con determinados rangos sociales (Marcus 2006: 217-218). Ello se refuerza, además, por la representación de gradas o peraltes, que enfatizan la composición escalonada. Esta, a su vez, le imprime profundidad a la escena, subraya el estatus de los individuos y produce una sensación de llegada a partir del exterior (Miller 1999: 116117, 157).

En ningún lugar podemos apreciar mejor estos recursos que en la Estela 12 de Piedras Negras (Figura 11), que define el rango de cada personaje mediante el principio de verticalidad. Mary E. Miller (1999: 123-124) observa que el rango de los individuos representados en esta estela también se encuentra en relación directa con el grado de profundidad en el relieve. Esto es, entre más profundo sea el relieve, mayor es la jerarquía social del personaje. K'ihnich Yakan Ahk II domina la composición al sentarse frontalmente en la cúspide de la escena, mientras coloca el pie derecho sobre su cautivo de Pomoná, adoptando una postura de relajamiento real (Schaffer 1991), y yergue la lanza con la punta 
hacia arriba, símbolo de superioridad ante figuras inferiores según Benson (1974: 112). Sus lugartenientes de La Mar se paran cual columnas a cada lado de la escena, mientras que en el extremo inferior del monumento gesticulan sentados y semidesnudos los prisioneros de menor rango.

El principio de verticalidad que se explota al máximo en esta estela de Piedras Negras era en realidad muy común en el arte maya. Por citar algún ejemplo, contamos con los vasos K767 y K3412 (ver Figura 3). La composición de ambos se divide en cuatro registros verticales. En el más elevado de ellos no encontramos al gobernante, sino a sus funcionarios de palacio: recaudadores de tributo o responsables de la administración cortesana (izquierda), así como los asistentes del monarca (derecha). Ello no implica que tengan mayor rango que el soberano, puesto que se encuentran de pie, utilizan indumentaria menos elaborada que la del rey y se distribuyen en lugares menos favorecidos: el área izquierda de la composición, detrás del respaldo del señor o a sus espaldas, cerca de la jamba o pilastra que enmarca la escena. El segundo nivel es el de la tarima forrada de esteras o petate que sirve como trono; el gobernante se sienta sobre ella vestido con una capa peluda de piel de mamífero, así como con un collar de colmillos de pecarí; el amplio cojín blanco que le sirve de respaldo ayuda a resaltar su imagen en contraste con un fondo neutro, al tiempo que le produce un hueco jerárquico que sirve para aislarlo y liberarlo del grupo. En un tercer nivel, y arrodillado sobre la grada superior de una plataforma escalonada, podemos observar al alto funcionario castrense cuyo tocado sugiere que llegó en las andas pintadas en la parte inferior izquierda de la escena. La línea negra que se extiende por el borde inferior de la vasija sirve como piso para un grupo de individuos de menor rango: el responsable de acondicionar la peana portátil, los guerreros que portan lanzas, los cautivos de guerra y el hombre arrodillado que sostiene el tributo (bultos de semillas, mantas de algodón apiladas y conchas spondylus) (Miller y Martin 2004: 184).

\section{Los cautivos y sus captores}

Las representaciones más frecuentes de cautivos son aquellas que los muestran atados, retorciéndose y gesticulando, mientras que el gobernante enaltece su poder al presentarse de pie frontalmente, asir la lanza con la punta hacia arriba, recibir la mirada de los demás y mantener su distancia física y emocional frente a ellos, lo que consigue mediante el espacio que lo enmarca, distingue y libera del grupo. Aunado a ello, podemos observar que la proporción y anchura de los captores o guerreros está ligeramente agrandada (Figura 12, ver Figura 10), recurso que encuentra su mejor expresión en las estelas ubicadas en las plazas, donde las figuras de los cautivos están consciente e intencionalmente empequeñecidas (Baudez y Mathews 1979: 32). El contraste deliberado de la escala podría haber agrandado el poder de estas esculturas para hacerlas imágenes imponentes ubicadas en lugares públicos. No obstante, conviene decir que este recurso también fue utilizado algunas veces en los vasos, como podemos observar en la vasija K1498.

Un dramático ejemplo del «motivo de la diferenciación» en el arte maya se encuentra en el Panel 2 de Piedras Negras (Figura 13), una escena con fuerte presencia de símbolos teotihuacanos, donde seis jóvenes de Bonampak, Lacanhá y Yaxchilán acuden a la corte de Diente de Tortuga (ca. 510 d.C.), gobernante de la ciudad de 


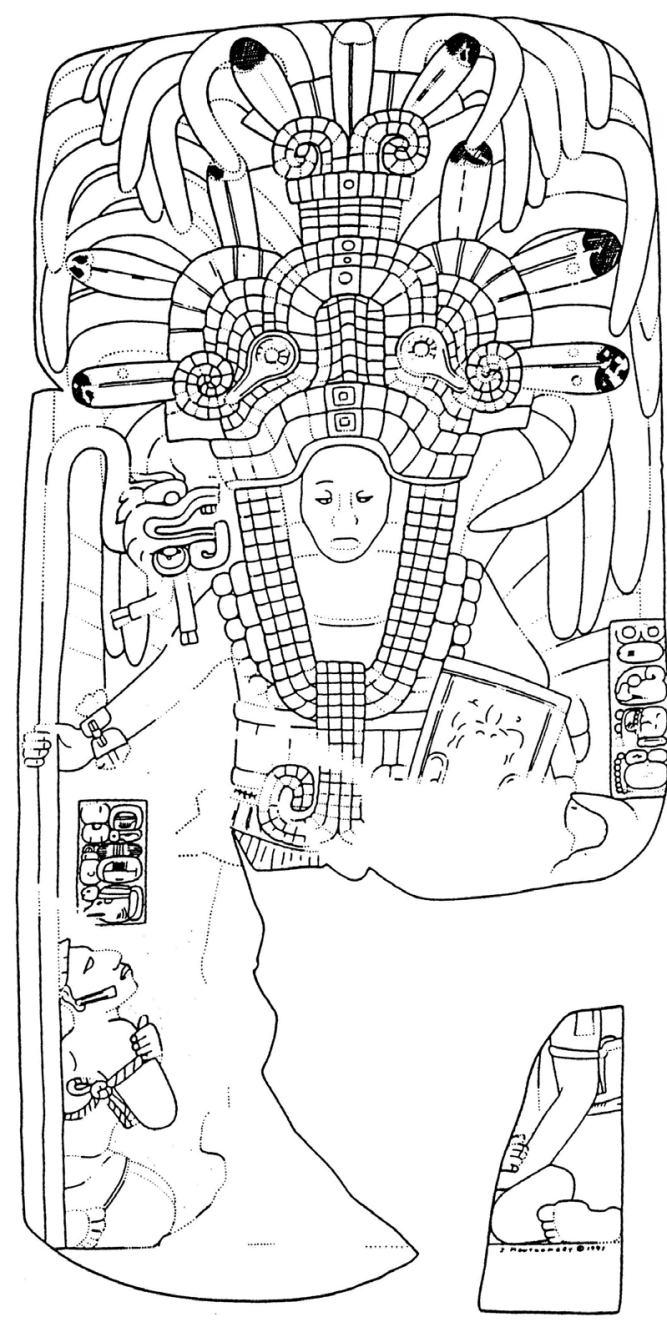

Figura 12. Estela 26 de Piedras Negras. El gobernante al presentarse de pie y frontal y recibir la mirada de los cautivos enaltece su poder. (Dibujo de J. Montgomery. Copyright (C) 2000 John Montgomery. http://research.famsi.org/uploads/ montgomery/536/image/JM05430.jpg).

Piedras Negras, para ser entrenados o educados en la guerra (Schele y Miller 1986: 148-150, 159, lám. 40; ReentsBudet et al. 1994: 103, nota 50; Martin 2001: 182; Martin y Grube 2008: 141, 144). Como Karl A. Taube (2000: 15-17, 51, nota 7) ha notado, las figuras de los seis jóvenes usan atuendos semejantes, asumen la misma postura corporal y sus identidades sólo se encuentran indicadas por los textos jeroglíficos que los nombran. Se trata de un canon artístico muy común en el centro de México, pero poco usual en el arte maya clásico (Taube 2000: 15-20; 2001: 63; 2002: 342-345). Esta suerte de fórmula pathos (ver Warburg 2005: 23$)^{7}$ revitalizando lo teotihuacano, entra en conflicto o tensión psicológica con la figura enhiesta, frontal, emplumada, orgullosa y de mayor escala de Diente de Tortuga, quien separado del resto del grupo asume una posición típicamente maya.

En el Panel 15 de Piedras Negras el rey y sus lugartenientes permanecen inexpresivos y ajenos al dolor manifestado por los prisioneros (Figura 14) ${ }^{8}$. Desde 1981 Virginia E. Miller señaló que en las escenas narrativas de carácter oficial existen muy

\footnotetext{
Pathosformel o fórmula pathos es un concepto muy complejo desarrollado a finales del siglo XIX por el gran historiador del arte Aby Warburg (1866-1929). En la biografía intelectual que sobre Warburg escribiera Ernest $\mathrm{H}$. Gombrich (1992), éste explica que pathos en griego significa «sufrimiento» o «emoción»: la reaparición o revitalización de formas artísticas idealizadas derivadas del mundo antiguo, insertadas de forma teatral y sorpresiva dentro de las artes visuales de un momento dado, produciendo una tensión, agitación dramática o exceso emocional. De este modo, mediante esta fórmula la autoridad y prestigio concedido al pasado clásico imprime en el arte una suerte de desahogo expresivo para liberar una energía vital contenida. Si bien la fórmula pathos encontrada por Warburg parece evocar una especie de energía liberadora al resucitar del pasado grecolatino formas especialmente dinámicas y en movimiento, la tensión emocional producida aquí por el artista maya al insertar formas estáticas y hieráticas teotihuacanas pudo también producir en el espectador indígena una tensión emocional sublime al conectar las composiciones cortesanas con ese pasado sagrado, anecuménico, teológico y distante, respaldado por el prestigio de la legendaria y arcana Teotihuacan.

8 Desde 1983 Miller (p. 24) advirtió que en las escenas narrativas de carácter oficial existen muy pocas interacciones entre las figuras principales y las subordinadas.
} 


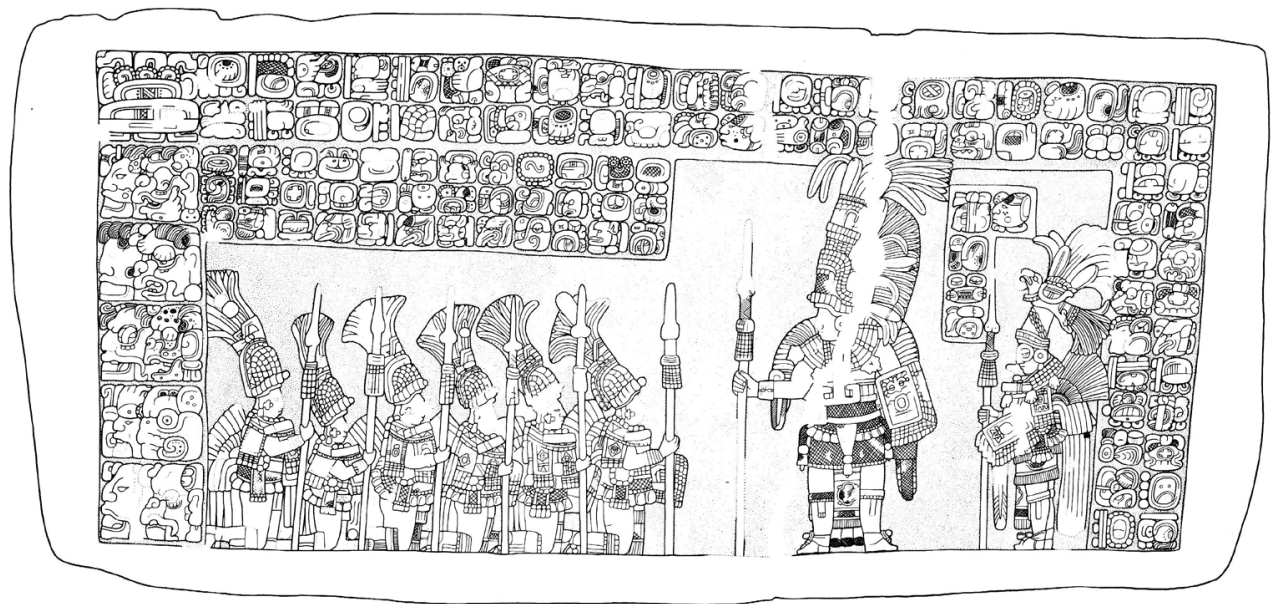

Figura 13. Panel 2 de Piedras Negras (667 d.C.). La figura del gobernante es de mayor escala que los seis jóvenes arrodillados ante él. (Dibujo de David Stuart, en Schele y Miller 1986: 149, Pl. 40a).

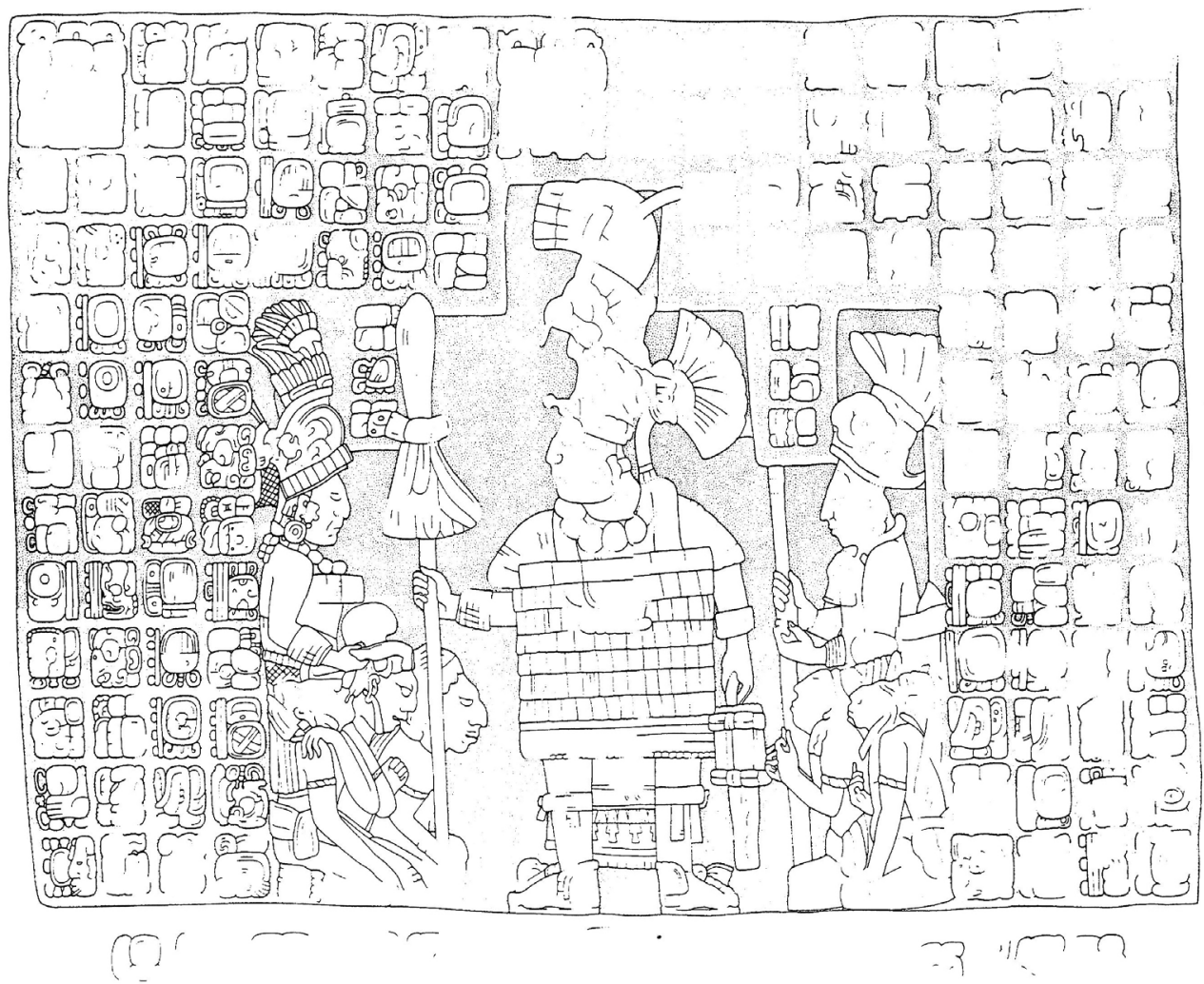

Figura 14. Panel 15 de Piedras Negras. El gobernante y sus representantes permanecen inexpresivos ante el dolor de los prisioneros (Houston 2001: 210, fig. 1). 
pocas interacciones entre las figuras principales y las subordinadas. Esta muestra de sentimientos autocontenidos y altamente regulados forma parte de un protocolo de mesura y dignidad de la nobleza maya, expresado con mayor rigor en los monumentos públicos que en los vasos, como ya fue mostrado por de la Fuente (1970: 17) y por Houston (2001: 209). De esta forma, la serenidad de los gobernantes victoriosos les otorga una propia majestad, y ésta les aparta de una participación directa en los incidentes de la escena. En el Panel 15 se puede observar que el primer cautivo de la izquierda -acaso el de menor jerarquía- coloca la mano izquierda sobre su hombro derecho. Como ha señalado Miller (1983: 34-36), este tipo de ejemplos han hecho suponer a varios estudiosos que el ademán ejecutado por estos cautivos constituye un gesto de sumisión (ver por ejemplo Baudez y Mathews, 1979: 32). Un conocido «saludo de paz y amistad» descrito por fray Diego López Cogolludo (1971-I: 223) en 1688 (Figura 15) ${ }^{9}$, y que durante el periodo Clásico pudo tener una connotación de sumisión.

\section{Reflexiones finales}

La representación sistemática de los ademanes y posturas corporales entre los escultores mayas sólo tuvo lugar durante el Clásico Tardío, cuando inició la producción frecuente de las escenas narrativas (Figura 15, ver Figura 8), si bien era un recurso que ya se conocía siglos antes en pintura mural y en ejemplos esporádicos labrados en piedra y o grabados en cerámica. Su función principal parece haber tenido que ver con señalar interrelaciones humanas que sirvieran para establecer la jerarquía relativa de los personajes y, con ello, enaltecer la imagen del gobernante. No obstante, el lenguaje gestual era sólo uno de los recursos para alcanzar este fin, pues en todas las escenas podemos apreciar un sistema de estrategias que incluía la representación de atuendos y parafernalia específica, el uso de títulos escritos de cargo y rango, la manipulación de volúmenes y escalas corporales, el principio de diferenciación de una figura dentro del grupo, el uso del hueco jerárquico, el escalonamiento vertical de los personajes y, muy especialmente, el lugar que ocupa cada individuo dentro de la composición, ya que el espacio pictórico no era para los artistas un campo indiferenciado, sino que estaba parcelado en áreas de mayor y de menor importancia. Una visión codificada y jerarquizada del espacio. Todos estos elementos, así como la relación que establecen los personajes entre sí, contribuyen a otorgarle un valor semántico a los ademanes y posturas corporales, pues es muy probable que éstos no tuvieran un significado intrínseco por sí mismos o de forma aislada, desasociados de este conjunto de estrategias. El repertorio de gestos que está representado en el arte maya clásico constituye un puñado de fórmulas que los artistas aprendían en los talleres, pues eran medios eficaces para transmitir información. Por tales motivos, su estudio no equivale a investigar la conducta corporal de los mayas clásicos, sino simplemente a desentrañar el sistema de convenciones visuales que era utilizado por los artistas. Además, no todas las posturas y ademanes deben tener algún tipo de significado. Algunos sólo desempeñaban funciones formales,

\footnotetext{
El pasaje narrado por López Cogolludo se refiere al viaje misionero que realizaron fray Juan de Orbita y fray Bartolomé de Fuensalida a Tayasal en 1618. Estando los religiosos en Tipú, fueron saludados por dos emisarios de Kaan Eek' (Canek). En 1701 fue repetido por fray Juan de Villagutierre Soto-Mayor (1984: 92): «luego que llegaron, saludaron los dos capitanes a los religiosos, a su usanza (que es echar el brazo derecho sobre el hombro, en señal de paz, y amistad)».
} 


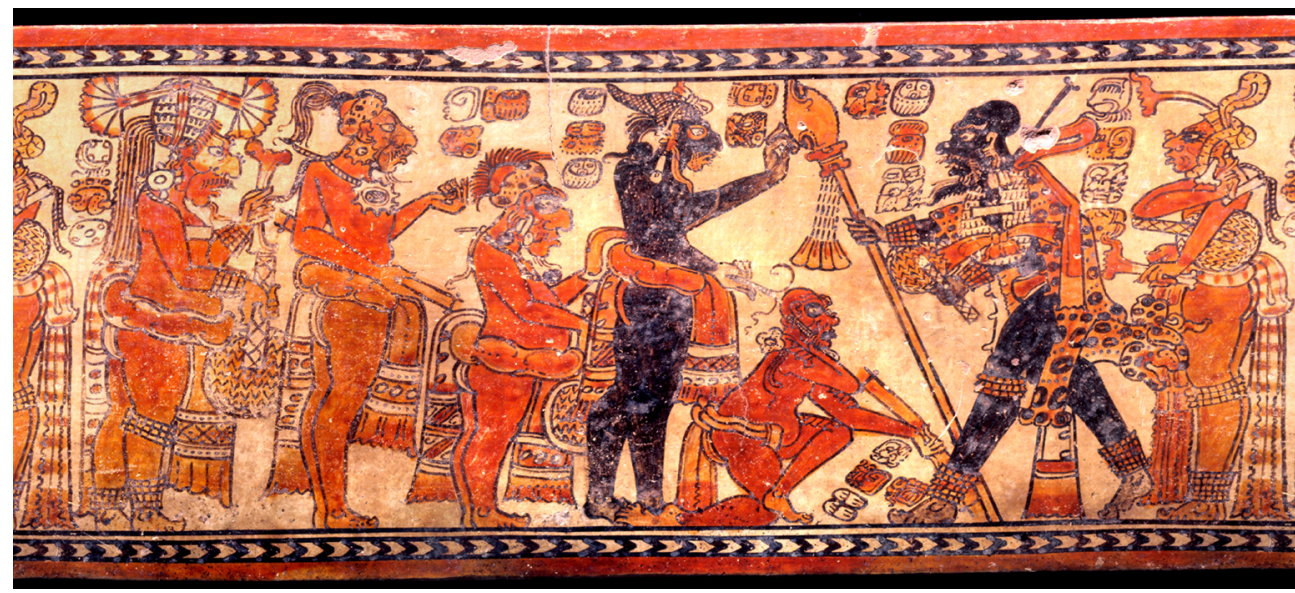

Figura 15: Vaso de Chamá. Encuentro de comerciantes, con dos de ellos en posición de saludo. (Cortesía de Justin Kerr, Justin Kerr Maya vase archive, K0593, Dumbarton Oaks, Trustees for Harvard University, Washington, D.C.).

pues servían para equilibrar cierta figura o composición, sugerir movimiento, introducir variación, atraer la mirada de los espectadores hacia cierto personaje, señalar condiciones generales de relajamiento, diálogo y relación entre individuos o coadyuvar en la representación de estereotipos sociales. Era el afán de claridad visual y no el de representar fielmente la realidad, la pauta que determinaba si determinado ademán se ejecutaba con el brazo izquierdo o con el derecho. No prevalecía el afán de representar la realidad tal como se ve, sino como se sabe de antemano que es, llegando a representar posturas corporales imposibles o muy incómodas, pero claras, inteligibles y nítidas para el observador. Finalmente, los artistas mayas parecen haber enfatizado la grandeza y sacralidad del gobernante a través de dos clases de tensión psicológica: a) aquella creada al introducir de forma teatral y dramatizada recursos hieráticos de tradición teotihuacana, y b) aquella creada por el distanciamiento inexpresivo y autocontenido del déspota señor divino, quien es indiferente a las bajas emociones del pueblo.

Es muy importante distinguir entre el énfasis visual concedido por los artistas a determinadas figuras o personajes de las escenas, y la jerarquía o estatus social que se supone tenían dentro del aparato cortesano, pues ambos aspectos o dimensiones no siempre coinciden. Aunque la importancia visual de una figura parece estar determinada por su cercanía física a la figura del mandatario, vemos que no siempre se trata de señores de alto rango, pues incluso puede tratarse de sirvientes, cautivos o asistentes que el artista subraya o enfatiza, pues el abismo social de sus jerarquías bajas ayuda a acentuar de forma dramática y contrastante la grandeza y majestad del soberano. En opinión mía, el k'uhul ajaw o mandatario maya era el centro gravitatorio de esta tradición visual-narrativa, el verdadero protagonista y tema de las escenas, alrededor del cual se construyó este entreverado -aunque flexible- sistema de estrategias que he comenzado a describir aquí.

Por último, conviene resaltar que una parte no despreciable del repertorio gestual empleado por los artistas mayas del Clásico parece haber sido utilizada también por los amanuenses del Posclásico Tardío. Algunos gestos pudieron transformar su función, mientras que otros puede que hayan conservado su aplicabilidad a los mismos 
contextos generales. Este es un problema que debe investigarse con mayor detenimiento en el futuro, pues parece constituir uno de los ingredientes estéticos que, con el devenir de los siglos, contribuyó a la cristalización del estilo conceptual e internacional llamado Mixteca-Puebla (Robertson 1963; Nicholson 1982).

\section{Referencias}

Ancona-Ha, Patricia, Jorge Pérez de Lara Elías y Mark Van Stone. 2000. «Some Observations on Hand Gestures in Maya Art», en The Maya Vase Book 6, Barbara y Justin Kerr, eds., pp. 1072-1089. Nueva York: Kerr Associates.

Baudez, Claude F. y Peter L. Mathews. 1979. «Capture and Sacrifice at Palenque», en Tercera Mesa Redonda de Palenque, 1978, Merle G. Robertson y Donnan C. Jeffers, eds., pp. 31-40. Monterrey: Pre-Columbian Art Research Center.

Benson, Elizabeth P. 1974. "Gestures and Offerings», en Primera Mesa Redonda de Palenque, Part 1. A Conference on the Art, Iconography, and Dynastic History of Palenque, Merle G. Robertson, ed., pp. 109-120. Pebble Beach: The Robert Louis Stevenson School, Pre-Columbian Art Research Institute.

Brilliant, Richard. 1963. Gesture and Rank in Roman Art. The Use of Gestures to Denote Status in Roman Sculpture and Coinage. New Haven: Memoirs of the Connecticut Academy of Arts and Sciences XIV.

Christenson, Allen J. 2003. Popol Vuh: The Sacred Book of the Maya. Winchester: O Books.

Culbert, T. Patrick. 1993. The Ceramics of Tikal: Vessels from the Burials, Caches, and Problematical Deposits. Tikal Report 25A. Filadelfia: The University Museum, University of Pennsylvania.

Escalante Gonzalbo, Pablo. 1996. El trazo, el cuerpo y el gesto. Los códices mesoamericanos y su transformación en el Valle de México en el siglo XVI. Un análisis del cambio histórico en el arte de la pictografía, con especial dedicación al problema de la representación del cuerpo humano, sus formas, sus posturas y sus ademanes. Tesis doctoral. Facultad de Filosofía y Letras. Universidad Nacional Autónoma de México.

Fuente, Beatriz de la. 1970. «El arte del retrato entre los mayas». Artes de México. Reseña del retrato mexicano 132: 7-22.

- 2004. «Espacio y tiempo en el arte», en El historiador frente a la historia. El tiempo en Mesoamérica, Virginia Guedea, coord., pp. 53-69. México: Instituto de Investigaciones Históricas, Universidad Nacional Autónoma de México.

Gombrich, Ernst H. 1987. «La máscara y el rostro: la percepción del parecido fisonómico en la vida y el arte», en La imagen y el ojo. Nuevos estudios sobre la psicología de la representación pictórica, pp. 99-127. Madrid: Alianza Editorial.

-1992. Aby Warburg. Una biografia intelectual. Madrid: Alianza Forma. . 2006. La historia del arte. Madrid: Phaidon Press Ltd.

Graham, Ian. 1967. Archaeological Explorations in El Peten, Guatemala. Middle American Research Institute 33. Nueva Orleans: Tulane University.

Halperin, Christina T. 2004. «Realeza maya y figurillas con tocados de la Serpiente de Guerra de Motul de San José, Guatemala». Mayab 17: 45-60.

Houston, Stephen D. 1998. «Classic Maya Depictions of the Built Environment», en Function and Meaning in Classic Maya Architecture, Stephen D. Houston, ed., pp. 333372. Washington, D.C.: Dumbarton Oaks Research Library and Collection.

- 2001. «Decorous Bodies and Disordered Passions: Representations of Emotion among the Classic Maya». World Archeology 33 (2): 206-219. 
2004. «Writing in Early Mesoamerica», en The First Writing. Script Invention as History and Process, Stephen D. Houston, ed., pp. 274-309. Cambridge: Cambridge University Press.

Houston, Stephen D. y David Stuart. 2001. «Peopling the Classic Maya Court», en Royal Courts of the Ancient Maya. Volume One: Theory, Comparison, and Synthesis, Takeshi Inomata y Stephen D. Houston, eds. pp. 54-83. Boulder: Westview Press.

Just, Bryan. 2012. Dancing into Dreams. Maya Vase Painting of the Ik'Kindom. Princeton: Princeton University Art Museum, Yale University Press.

Kerr, Justin. 2000. Maya Vase. Data Base. An Archive of Rollout Photographs Created by Justin Kerr. Foundation for the Advancement of Mesoamerican Studies, Inc. (FAMSI). http://research.mayavase.com/kerrmaya.html.

Looper, Mathew G. 2003. Lightning Warrior: Maya Art and Kingship at Quiriguá. Austin: University of Texas Press.

López Austin, Alfredo. 2015. «Tiempo del ecúmeno, tiempo del anecúmeno. Propuesta de un paradigma», en El tiempo de los dioses-tiempo. Concepciones de Mesoamérica, Mercedes de la Garza, coord., pp. 11-49. México: Centro de Estudios Mayas, Instituto de Investigaciones Filológicas, Universidad Nacional Autónoma de México.

López Cogolludo, fray Diego. 1971. Los tres siglos de la dominación española en Yucatán o sea historia de esta provincia. Graz: Akademische Druck-u. Verlagsanstalt.

Marcus, Joyce. 2006. «Identifying Elites and their Strategies», en Intermediate Elites in PreColumbian States and Empires, Christina M. Elson y R. Alan Covey, eds., pp. 212-246. Tucson: The University of Arizona Press.

Martin, Simon. 2001. «Court and Realm: Architectural Signatures in the Classic Maya Southern Lowlands», en Royal Courts of the Ancient Maya. Volume One: Theory, Comparison, and Synthesis, Takeshi Inomata y Stephen D. Houston, eds., pp. 168-194. Boulder: Westview Press.

Martin, Simon y Nikolai Grube. 2008. Chronicle of the Maya Kings and Queens. Deciphering the Dynasties of the Ancient Maya. $2^{\text {a }}$ edición. Londres: Thames and Hudson.

Miller, Mary E. 1999. Maya Art and Architecture. Londres: Thames and Hudson.

—. 2009. Arte y arquitectura maya. México: Fondo de Cultura Económica.

Miller Mary E. y Claudia Brittenham. 2013. The Spectacle of the Late Maya Court: Reflections on the Murals of Bonampak. Austin y México: University of Texas Press, Consejo Nacional para la Cultura y las Artes, Instituto Nacional de Antropología e Historia.

Miller, Mary E. y Simon Martin. 2004. Courtly Art of the Ancient Maya. Nueva York: Thames and Hudson.

Miller, Virginia E. 1981. Pose and Gesture in Classic Maya Monumental Sculpture. Tesis Doctoral. The University of Texas at Austin.

- 1983. «A Reexamination of Maya Gestures of Submission». Journal of Latin American Lore 9 (1): 17-38.

Nicholson, Henri B. 1982. «The Mixteca-Puebla Concept Revisited», en The Art and Iconography of Late Post-Classic Central Mexico, Elizabeth H. Boone, ed., pp. 227-254. Washington, D.C.: Dumbarton Oaks Research Library and Collection.

Palka, Joel. 2002. «Left/Right Symbolism and the Body in Ancient Maya Iconography and Culture». Latin American Antiquity 13 (4): 419-443.

Pérez de Lara, Jorge. 2002. «A Look at the Hand and Arm Gestures of the Chararcters on the Palenque Temple XIX Bench». Mesoweb Articles. http://www.mesoweb.com/features/ gestures/index.html. 
Proskouriakoff, Tatiana A. 1950. A Study of Classic Maya Sculpture. Carnegie Institution of Washington 593. Washington, D.C.: Carnegie Institution.

Reents-Budet, Dorie J. 2001. «Classic Maya Concepts of the Royal Court. An Analysis of Renderings on Pictorial Ceramics», en Royal Courts of the Ancient Maya. Volume One: Theory, Comparison, and Synthesis, Takeshi Inomata y Stephen D. Houston, eds., pp. 195-233. Boulder: Westview Press.

Reents-Budet, Dorie J., Joseph W. Ball, Ronald L. Bishop, Virginia M. Fields y Barbara Macleod. 1994. Painting the Maya Universe: Royal Ceramics of the Classic Period. Durham: Duke University Press.

Robertson, Donald. 1963. «The Style of the Borgia Group of Mexican Pre-Conquest Manuscripts», en Latin American Art, and the Baroque Period in Europe. Studies in Western Art. Acts of the Twentieh International Congress of the History of Art, Vol. III, pp. 148164. Princeton: Princeton University Press.

Robicsek, Francis y Donald M. Hales. 1981. The Maya Book of the Dead. The Ceramic Codex. Norman: University of Oklahoma Press.

Shaffer, Anne-Louise. 1991. «Maya Posture of Royal Ease», en Sixth Palenque Round Table, 1986, Virginia M. Fields, ed., pp. 203-2016. Norman: University of Oklahoma Press.

Schele, Linda y Mary E. Miller. 1986. The Blood of Kings. Dynasty and Ritual in Maya Art. Nueva York y Fort Worth: George Braziller, Inc. y Kimbell Art Museum.

Schumann Gálvez, Otto. 1981. «La relación lingüística chuj-tojolabal», en Los legítimos hombres. Aproximación antropológica al grupo tojolabal, Vol. I, Mario Humberto Ruz, ed., pp. 129-169. México: Centro de Estudios Mayas, Instituto de Investigaciones Filológicas, Universidad Nacional Autónoma de México.

Stuart, David e Ian Graham. 2003. Corpus of Maya Hieroglyphic Inscriptions, Vol. 9, Part 1, Piedras Negras. Cambridge: Peabody Museum of Archaeology and Ethnology, Harvard University.

Taube, Karl A. 2000. The Writing System of Ancient Teotihuacan. Ancient America 1. Washington, D.C.: Center for Ancient American Studies.

- 2001. «La escritura teotihuacana». Arqueología Mexicana 48: 58-63.

. 2002. «The Writing System of Ancient Teotihuacan», en Ideología y política a través de materiales, imágenes y símbolos. Memorias de la Primera Mesa Redonda de Teotihuacan, María Elena Ruiz Gallut, ed., pp. 331-370. México: Consejo Nacional para la Cultura y las Artes, Instituto Nacional de Antropología e Historia, Instituto de Investigaciones Estéticas, Instituto de Investigaciones Antropológicas, Universidad Nacional Autónoma de México.

Velásquez García, Erik. 2009. Los vasos de la entidad política de 'Ik': Una aproximación histórico-artística. Estudios sobre las entidades anímicas y el lenguaje gestual y corporal en el arte maya clásico. Tesis doctoral. Facultad de Filosofía y Letras, Universidad Nacional Autónoma de México.

Villagutierre Soto-Mayor, Juan de. 1984 (1701). Historia de la conquista de la provincia de El Itza. México: Grupo Condumex.

Warburg, Aby. 2005. El renacimiento del paganismo. Aportaciones a la historia del Renacimiento europeo. Madrid: Alianza Editorial.

Winning, Hasso von. 1987. La iconografia de Teotihuacan. Los dioses y los signos. Estudios y Fuentes del Arte en México XLVII, Vol. II. México: Instituto de Investigaciones Estéticas, Universidad Nacional Autónoma de México. 